\title{
Damage caused by Meloidogyne javanica and Pratylenchus zeae to sugarcane cultivars
}

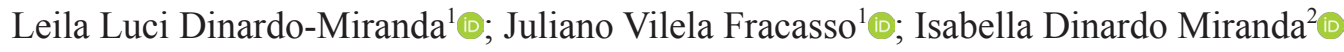

${ }^{1}$ Instituto Agronômico, Centro de Cana, Rodovia Antonio Duarte Nogueira, km 321, Ribeirão Preto, SP, Brazil, CEP 14001-970. ${ }^{2}$ DMLab - Análises agrícolas e Agricultura de Precisão; Av. Patriarca, 1840; Ribeirão Preto, SP, Brasil, CEP 14031-580

Autor para correspondência: Leila Luci Dinardo-Miranda (leiladinardo@iac.sp.gov.br)

Data de chegada: 13/11/2017 Aceito para publicação em: 04/02/2019.

$10.1590 / 0100-5405 / 187782$

\section{ABSTRACT}

Dinardo-Miranda, L.L.; Fracasso, J.V.; Miranda, I.D. Damage caused by Meloidogyne javanica and Pratylenchus zeae to sugarcane cultivars. Summa Phytopathologica, v.45, n.2, p.146-156, 2019.

\begin{abstract}
Nematodes are important parasites of sugarcane, significantly reducing the yield and the longevity of the crop. Damage caused by them varies with the susceptibility of sugarcane cultivars; thus, it is important for growers to learn the reaction of new genotypes in order to better direct control measures. The objective of this study was to evaluate the damage caused by nematodes to cultivars newly released for commercial planting. Two experiments were conducted in fields infested by Meloidogyne javanica and Pratylenchus zeae. Both experiments were arranged in split-plot randomized block design. The cultivars were planted in the plots, and two carbofuran 350SC levels, 0 and
\end{abstract}

$7 \mathrm{~L} \mathrm{ha}^{-1}$, were applied on two subplots (treated and non-treated subplots). On average, the subplots treated with the nematicide had their yield increased by $10 \%$, compared to non-treated subplots, suggesting that nematodes reduced the yield of cultivars by at least $10 \%$, but such a reduction reached $22 \%$ for cultivar IACSP97-7569 in experiment 1 and 17\% for CTC20 in experiment 2. Damage was insignificant for cultivars CTC9001, CTC9002, IACSP93-3046, IACSP95-5094, IACSP96-3060, IACSP97-4039 and RB975952 in experiment 1 and for cultivars IACSP97-4039, RB867515 and RB966928 in experiment 2.

These cultivars can be considered tolerant to M. javanica and P. zeae.

Keywords: plant-parasitic nematodes, tolerance, susceptibility.

\section{RESUMO}

Dinardo-Miranda, L.L.; Fracasso, J.V.; Miranda, I.D. Danos causados por Meloidogyne javanica e Pratylenchus zeae a cultivares de cana-deaçúcar. Summa Phytopathologica, v.45, n.2, p.146-156, 2019.

Nematoides são importantes parasitos da cana-de-açúcar, reduzindo significantemente a produtividade e a longevidade da cultura. Os danos causados por eles variam com a suscetibilidade da cultivar, razão pela qual é importante para os produtores conhecer a resposta dos novos genótipos, a fim de direcionar as medidas de controle. Assim, o objetivo do presente trabalho foi avaliar o dano causado por nematoides a cultivares de cana-de-açúcar recém lançadas para plantio comercial. Dois experimentos foram conduzidos em áreas infestadas por Meloidogyne javanica e Pratylenchus zeae. Ambos os ensaios foram conduzidos segundo o delineamento de blocos ao acaso, com parcelas subdivididas. As cultivares foram plantadas nas parcelas e duas doses de carbofuran 350SC, 0 and $7 \mathrm{~L} \mathrm{ha}^{-1}$, foram aplicadas às subparcelas (tratada e não tratada). Na média, subparcelas tratadas com nematicidas produziram $10 \%$ mais que as não tratadas, sugerindo que os nematoides reduziram a produtividade das cultivares em pelo menos $10 \%$, mas a redução atingiu $22 \%$ na cultivar IACSP97-7569, no experimento 1 e $17 \%$ na CTC20, no experimento 2 . O dano foi insignificante nas cultivares CTC9001, CTC9002, IACSP93-3046, IACSP95-5094, IACSP96-3060, IACSP97-4039 e RB975952, no experimento 1 e nas cultivares IACSP97-4039, RB867515 e RB966928 no experimento 2. Essas cultivares podem ser consideradas tolerantes M. javanica e $P$. zeae.

Palavras-chave: nematoides parasitos de plantas, tolerância, suscetibilidade.

A large number of plant-parasitic nematodes are associated with sugarcane in Brazil, but Pratylenchus zeae Graham, P. brachyurus (Godfrey) Filipjev \& Schuurmans Stekhoven, Meloidogyne javanica Treub) Chitwood and M. incognita (Kofoid \& White) are the most important species due to the damage they cause to the crop $(10,17,19)$, which varies with the occurring species, the population density, the soil type and the sugarcane cultivar (10). On average, nematodes reduce the yield by around 20 to $40 \%$ in the first cycle (plant-cane), reaching more than $50 \%$ in cases of large populations and highly susceptible cultivars. In the ratoon, the yield is also reduced, compromising the crop longevity, which needs to be renewed more frequently in infested areas $(5,8,9,10,20)$.

Management of the infested areas is done by integrating several control tools with the aim of reducing the population of these parasites to a level lower than that capable of causing damage to the crop. Among alternatives to reduce the nematode population in sugarcane fields, at least for a few months, nematicides are undoubtedly the most used method (10).

Although the introduction of resistant cultivars is definitely one of the most useful methods to reduce nematode populations (15), cultivars resistant to at least one economically important nematode species $(M$. javanica, M. incognita, P. zeae and P. brachyurus) are currently scarce. Only one of the cultivars commonly planted nowadays (IACSP93-3046) is considered resistant to M. javanica (6). Moreover, when resistance is detected in a particular cultivar, it is usually restricted to one nematode species. As two or more nematodes frequently occur in the same field, using a cultivar that is resistant to only one nematode species is not effective (10).

In addition, the damage caused by nematodes is known to vary with the cultivar, as observed by Dinardo-Miranda et al. (6). In a field 
infested by $M$. javanica, those authors compared the yield of plots treated with the nematicide to that of non-treated plots and estimated that some cultivars had a yield reduction of $8 \%$ due to nematodes, while others showed no reduction.

Considering such differences among cultivars for the damage caused by nematodes, it is important for growers to learn the behavior of new cultivars to better direct control measures. Thus, the objective of this study was to evaluate the damage caused by $M$. javanica and $P$. zeae to newly released cultivars.

\section{MATERIAL AND METHODS}

Two experiments were conducted: experiment 1 was carried out in Guapiaçu, SP, Brazil (2046'16"S and 49 $08^{\circ} 32^{\prime}$ 'W) and experiment 2 was performed in Ribeirão Preto, SP, Brazil (21 $18^{\prime} 31^{\prime}$ S and $\left.47^{\circ} 67^{\prime} 12^{\prime \prime} \mathrm{W}\right)$, both in sandy soil areas.

Both experiments were arranged in split-plot randomized block design and five (experiment 1) or six (experiment 2) replicates. A plot was represented by 1210 -m furrows spaced $1.5 \mathrm{~m}$ apart, and each plot was divided into two sub-plots of 6 furrows. Cultivars were planted in the plots, and two carbofuran 350SC levels, 0 and $7 \mathrm{~L} \mathrm{ha}^{-1}$, were applied on the two subplots (treated and non-treated subplots).

The following cultivars were evaluated: CTC9001, CTC9002, CTC9003, IACSP93-3046, IACSP95-5000, IACSP95-5094, IACSP96-3060, IACSP96-7569, IACSP97-4039, RB965902, RB975201, RB975242 and RB975952 in experiment 1, and CTC4, CTC20, IACSP95-5000, IACSP96-3060, IACSP96-7569, IACSP97-4010, IACSP97-4039, RB855156, RB855453, RB867515, RB966928 and SP83-2847 in experiment 2. In both experiments, IACSP95-5000 was used as a susceptible standard (10).

Planting occurred on April 4, 2015, for experiment 1, and on April 14,2015 , for experiment 2 . The nematicide was applied on each furrow with a $\mathrm{CO}_{2}$ pressurized backpack sprayer equipped with 11003 spray tip, at a working pressure of 30 PSI for a $150 \mathrm{~L} \mathrm{ha}^{-1}$ flow. Immediately after nematicide application, furrows were covered with soil.

Nematode populations were evaluated on June 10, 2015, November 11, 2015, and February 5, 2016, i.e., at two, seven and ten months after planting for experiment 1, and on June 8, 2015, October 10, 2015, and January 8, 2016, i.e., at two, six and nine months after planting for experiment 2. Each of those evaluations consisted in collecting plant roots and soil from the first and sixth furrows of each subplot and extracting nematodes by combining sieving and centrifugation with sucrose solution $(3,13)$.

The yield of each subplot in experiment 1 was obtained on April 4,2016 , considering stalks from the second to the fifth furrow. In this case, the yield was obtained based on the biometric method described by Landell et al. (14); the yields in experiment 2 were obtained on August 10, 2016, by cutting and weighing all stalks from the second to the fifth furrow of subplots.

For statistical analysis, the population data were transformed by using the square root of $(x+1)$. All data were subjected to analysis of variance, and means were compared according to $t$ test, using the SAS software program (21).

\section{RESULTS AND DISCUSSION}

Among the most important nematode species for sugarcane, $M$. javanica and $P$. zeae were identified in both experimental fields.

Two months after planting, $M$. javanica populations were small in experiments 1 and 2, considering both plant roots and soil. $P$. zeae specimens were found in all cultivars, especially in plant roots in experiment 1, but were found at a smaller number and were not obtained from soil in experiment 2, suggesting that the population was particularly small (Tables 1-4). Small nematode populations at the first sampling can be attributed to mild temperatures and low soil moisture due to low rainfall in the areas after planting (Table 5).

Nematode growth and development are directly affected by temperature (18), which also interferes in dormancy, diapause (12) and life cycle (16). In experiments 1 and 2, minimum air temperatures during the first two months after planting were near $15^{\circ} \mathrm{C}$, suggesting that the soil temperature could have reached limiting values for nematode development. However, small populations were probably due to low soil moisture. In tropical areas, as well as in the areas where the present experiments were conducted, of relatively minor seasonal temperature fluctuation, seasonal patterns of rainfall have mayor influence on nematode populations (2). Soil moisture is critical for nematode mobility and activity (22) and was extremely low in the experimental areas soon after planting due to low rainfall (Table 5).

Low temperature and soil moisture also indirectly affect nematode population by interfering in root development. During periods of low air temperatures and, consequently, low soil temperatures, root growth decreases $(16,23)$, hampering the growth of plant-parasitic nematodes.

On average, two months after planting, nematode populations were smaller in plant roots treated with the nematicide, compared to non-treated ones, in both experiments; however, differences between treated and non-treated subplots in relation to nematode populations were found for a few cultivars (Tables 1 and 3).

In the second sampling, at six or seven months after planting, and in the third sampling, during the rainy season - January or February, the populations of both nematode species were larger than those at the first sampling, in experiments 1 and 2. However, differences between treated and non-treated subplots were observed only for some cultivars (Tables 1-4), suggesting that the nematicide had already lost its efficiency. In experiment 1 , on average, plant roots from treated subplots had more nematodes than those from non-treated subplots (Table 1), which is common in commercial areas. This is possibly due to the reduction caused by the nematicide in the nematode population, which consequently provides better root development, compared to non-treated plants; therefore, the conditions for nematode multiplication are better when the product effect ends.

Suitability of host cultivars to nematodes was evaluated by considering data from samplings in which the nematode population was large: in experiment 1 , host suitability to $M$. javanica was assessed by considering data from the second and third samplings and host suitability to $P$. zeae was obtained by using data from the three samplings. In experiment 2, only data from the third sampling was considered, both to M. javanica and to P. zeae.

In experiment 1 , the largest populations of $M$. javanica in roots were recorded for cultivars RB975952, RB965902 and IACSP96-3060, which were considered therefore good hosts (Table 6). The smallest population of M. javanica was recorded for cultivar IACSP93-3046 (Table 6), which was already reported by Dinardo-Miranda et al. (6) to be resistant to $M$. javanica under field conditions. Dinardo-Miranda and Fracasso (7), carrying out an experiment in 64-L pots, also considered IACSP93-3046 a poor host to M. javanica since the reproduction factor of this nematode species was lower than 1 for this cultivar. 
Table 1. Population of second-stage juveniles of Meloidogyne javanica (Mj) and population of juveniles and adults of Pratylenchus zeae (Pz) in roots $(50 \mathrm{~g})$ of cultivars, treated $(\mathrm{T})$ and non-treated $(\mathrm{NT})$ with nematicide, according to sampling data in experiment 1.

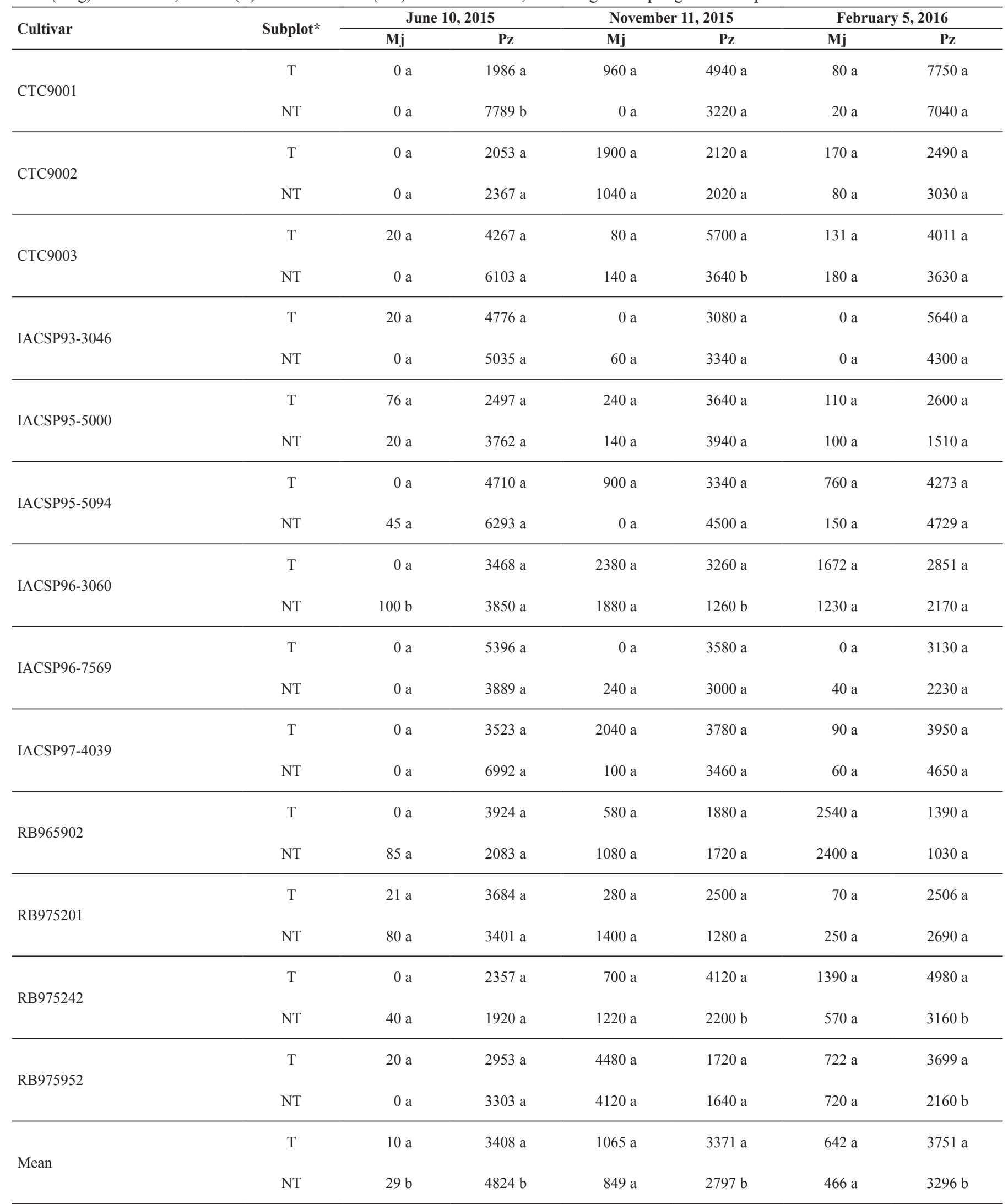

* Treated (T) and non-treated (NT) with nematicide. Means within the same cultivar and in the same column, followed by the same letter, are not significantly different ( $\mathrm{t}$ test, $\mathrm{p} \leq 1)$. 
Table 2. Population of second-stage juveniles of Meloidogyne javanica (Mj) and population of juveniles and adults of Pratylenchus zeae (Pz) in soil (1 L) of cultivars, treated (T) and non-treated (NT) with nematicide, according to sampling data in experiment 1.

\begin{tabular}{|c|c|c|c|c|c|c|c|}
\hline \multirow{2}{*}{ Cultivar } & \multirow{2}{*}{ Subplot* } & \multicolumn{2}{|c|}{ June 10, 2015} & \multicolumn{2}{|c|}{ November 11, 2015} & \multicolumn{2}{|c|}{ February 5, 2016} \\
\hline & & $\mathbf{M j}$ & $\mathbf{P z}$ & $\mathbf{M j}$ & $\mathbf{P z}$ & $\mathbf{M j}$ & $\mathbf{P z}$ \\
\hline СТC9001 & $\mathrm{T}$ & $0 \mathrm{a}$ & $240 \mathrm{a}$ & $108 \mathrm{a}$ & $120 \mathrm{a}$ & $408 \mathrm{a}$ & $2184 \mathrm{a}$ \\
\hline CTC9002 & $\mathrm{T}$ & $12 \mathrm{a}$ & $156 \mathrm{a}$ & $36 \mathrm{a}$ & $60 \mathrm{a}$ & $168 \mathrm{a}$ & $576 \mathrm{a}$ \\
\hline \multirow[b]{2}{*}{ СТC9003 } & $\mathrm{T}$ & $36 \mathrm{a}$ & $336 \mathrm{a}$ & $0 \mathrm{a}$ & $84 \mathrm{a}$ & $0 \mathrm{a}$ & $1200 \mathrm{a}$ \\
\hline & NT & $252 \mathrm{~b}$ & $432 \mathrm{a}$ & $12 \mathrm{a}$ & $108 \mathrm{a}$ & $108 \mathrm{a}$ & $552 \mathrm{~b}$ \\
\hline IACSP93-30 & $\mathrm{T}$ & $12 \mathrm{a}$ & $264 \mathrm{a}$ & $0 \mathrm{a}$ & $132 \mathrm{a}$ & $0 \mathrm{a}$ & $1212 \mathrm{a}$ \\
\hline IACSP95 & NT & $0 \mathrm{a}$ & $168 \mathrm{a}$ & $0 \mathrm{a}$ & $168 \mathrm{a}$ & $12 \mathrm{a}$ & $456 \mathrm{a}$ \\
\hline \multirow{2}{*}{ IACSP95- } & $\mathrm{T}$ & $0 \mathrm{a}$ & $396 \mathrm{a}$ & $0 \mathrm{a}$ & $84 \mathrm{a}$ & $300 \mathrm{a}$ & $780 \mathrm{a}$ \\
\hline & NT & $0 \mathrm{a}$ & $360 \mathrm{a}$ & $0 \mathrm{a}$ & $288 \mathrm{~b}$ & $48 \mathrm{a}$ & $1476 \mathrm{~b}$ \\
\hline \multirow{2}{*}{ IACSP96 } & $\mathrm{T}$ & $12 \mathrm{a}$ & $276 \mathrm{a}$ & $420 \mathrm{a}$ & $48 \mathrm{a}$ & $1956 \mathrm{a}$ & $708 \mathrm{a}$ \\
\hline & NT & $0 \mathrm{a}$ & $120 \mathrm{a}$ & $528 \mathrm{a}$ & $36 \mathrm{a}$ & $1356 \mathrm{a}$ & $696 \mathrm{a}$ \\
\hline \multirow{2}{*}{ RB965902 } & $\mathrm{T}$ & $0 \mathrm{a}$ & $408 \mathrm{a}$ & $36 \mathrm{a}$ & $60 \mathrm{a}$ & 2436 a & $552 \mathrm{a}$ \\
\hline & NT & $48 \mathrm{a}$ & $204 \mathrm{a}$ & $180 \mathrm{a}$ & $24 \mathrm{a}$ & $3460 \mathrm{a}$ & $192 \mathrm{~b}$ \\
\hline \multirow[b]{2}{*}{ RB975201 } & $\mathrm{T}$ & $0 \mathrm{a}$ & $336 \mathrm{a}$ & $0 \mathrm{a}$ & $36 \mathrm{a}$ & $48 \mathrm{a}$ & $468 \mathrm{a}$ \\
\hline & NT & $0 \mathrm{a}$ & $204 \mathrm{a}$ & $36 \mathrm{a}$ & $60 \mathrm{a}$ & $204 \mathrm{a}$ & $276 \mathrm{a}$ \\
\hline \multirow[b]{2}{*}{ RB975242 } & $\mathrm{T}$ & $0 \mathrm{a}$ & $156 \mathrm{a}$ & $180 \mathrm{a}$ & $72 \mathrm{a}$ & $372 \mathrm{a}$ & $1128 \mathrm{a}$ \\
\hline & NT & $48 \mathrm{a}$ & $288 \mathrm{a}$ & $108 \mathrm{a}$ & $132 \mathrm{~b}$ & $72 b$ & $780 \mathrm{a}$ \\
\hline \multirow[b]{2}{*}{ RB975952 } & $\mathrm{T}$ & $0 \mathrm{a}$ & $360 \mathrm{a}$ & $24 \mathrm{a}$ & $24 \mathrm{a}$ & $828 \mathrm{a}$ & $1380 \mathrm{a}$ \\
\hline & NT & $12 \mathrm{a}$ & $324 \mathrm{a}$ & $552 \mathrm{a}$ & $36 \mathrm{a}$ & $756 \mathrm{a}$ & $624 \mathrm{~b}$ \\
\hline \multirow{3}{*}{ Mean } & $\mathrm{T}$ & $29 \mathrm{a}$ & $297 \mathrm{a}$ & $77 \mathrm{a}$ & $76 \mathrm{a}$ & $531 \mathrm{a}$ & $923 \mathrm{a}$ \\
\hline & & & & & & & \\
\hline & NT & $5 \mathrm{a}$ & $277 \mathrm{a}$ & $111 \mathrm{a}$ & $109 \mathrm{a}$ & $384 \mathrm{~b}$ & $849 a$ \\
\hline
\end{tabular}

* Treated (T) and non-treated (NT) with nematicide. Means within the same cultivar and in the same column, followed by the same letter, are not significantly different ( $\mathrm{t}$ test, $\mathrm{p} \leq 1)$. 
Table 3. Population of second-stage juveniles of Meloidogyne javanica (Mj) and population of juveniles and adults of Pratylenchus zeae (Pz) in roots $(50 \mathrm{~g})$ of cultivars, treated (T) and non-treated (NT) with nematicide, according to sampling data in experiment 2.

\begin{tabular}{|c|c|c|c|c|c|c|c|}
\hline \multirow{2}{*}{ Cultivar } & \multirow{2}{*}{ Subplot* } & \multicolumn{2}{|c|}{ June 8, 2015} & \multicolumn{2}{|c|}{ October 20, 2015} & \multicolumn{2}{|c|}{ January 8, 2016} \\
\hline & & $\mathbf{M j}$ & $\mathrm{Pz}$ & $\mathbf{M j}$ & $\mathrm{Pz}$ & $\mathbf{M j}$ & $\mathbf{P z}$ \\
\hline & $\mathrm{T}$ & $16 \mathrm{a}$ & $800 \mathrm{a}$ & $217 \mathrm{a}$ & $2250 \mathrm{a}$ & $5317 \mathrm{a}$ & $4267 \mathrm{a}$ \\
\hline \multicolumn{8}{|r|}{$14350 \mathrm{a}$} \\
\hline \multicolumn{8}{|c|}{ IACSP95-5000 } \\
\hline & NT & $0 \mathrm{a}$ & $1221 \mathrm{~b}$ & $400 \mathrm{a}$ & $1583 \mathrm{a}$ & $2700 \mathrm{a}$ & $7617 b$ \\
\hline \multicolumn{8}{|c|}{ IACSP96-3060 } \\
\hline \multicolumn{8}{|c|}{ IACSP96-7569 } \\
\hline & NT & $133 \mathrm{a}$ & $1233 \mathrm{~b}$ & $0 \mathrm{a}$ & $1950 \mathrm{a}$ & $1167 \mathrm{a}$ & $9983 \mathrm{a}$ \\
\hline \multicolumn{8}{|c|}{ IACSP97-4010 } \\
\hline & NT & $0 \mathrm{a}$ & $967 \mathrm{~b}$ & $400 \mathrm{a}$ & $2283 \mathrm{a}$ & $4800 \mathrm{a}$ & $13533 \mathrm{~b}$ \\
\hline \multicolumn{8}{|c|}{ IACSP97-4039 } \\
\hline \multicolumn{8}{|c|}{ RB855156 } \\
\hline \multicolumn{7}{|c|}{ RB855453 } & $6333 \mathrm{a}$ \\
\hline \multirow{2}{*}{\multicolumn{8}{|c|}{ RB867515 }} \\
\hline & & & & & & & \\
\hline & NT & $33 \mathrm{a}$ & $1130 \mathrm{a}$ & $833 \mathrm{a}$ & $3250 \mathrm{~b}$ & $5467 \mathrm{a}$ & $9950 \mathrm{~b}$ \\
\hline \multirow{2}{*}{\multicolumn{8}{|c|}{ RB966928 }} \\
\hline & & & & & & & \\
\hline \multirow{2}{*}{\multicolumn{8}{|c|}{ SP83-2847 }} \\
\hline & & & & & & & \\
\hline & NT & $17 \mathrm{a}$ & $1015 \mathrm{a}$ & $517 \mathrm{~b}$ & $3883 \mathrm{a}$ & $4500 \mathrm{a}$ & $9250 \mathrm{~b}$ \\
\hline \multirow{2}{*}{\multicolumn{8}{|c|}{$4132 \mathrm{a}$}} \\
\hline & & & & & & & \\
\hline & NT & $41 \mathrm{a}$ & $1012 \mathrm{~b}$ & $509 \mathrm{a}$ & $2605 \mathrm{~b}$ & $3968 \mathrm{a}$ & $8661 \mathrm{~b}$ \\
\hline
\end{tabular}

* Treated (T) and non-treated (NT) with nematicide. Means within the same cultivar and in the same column, followed by the same letter, are not significantly different ( $t$ test, $\mathrm{p} \leq 1$ ). 
Table 4. Population of second-stage juveniles of Meloidogyne javanica (Mj) and population of juveniles and adults of Pratylenchus zeae (Pz) in soil (1 L) of cultivars, treated (T) and non-treated (NT) with nematicide, according to sampling data in experiment 2.

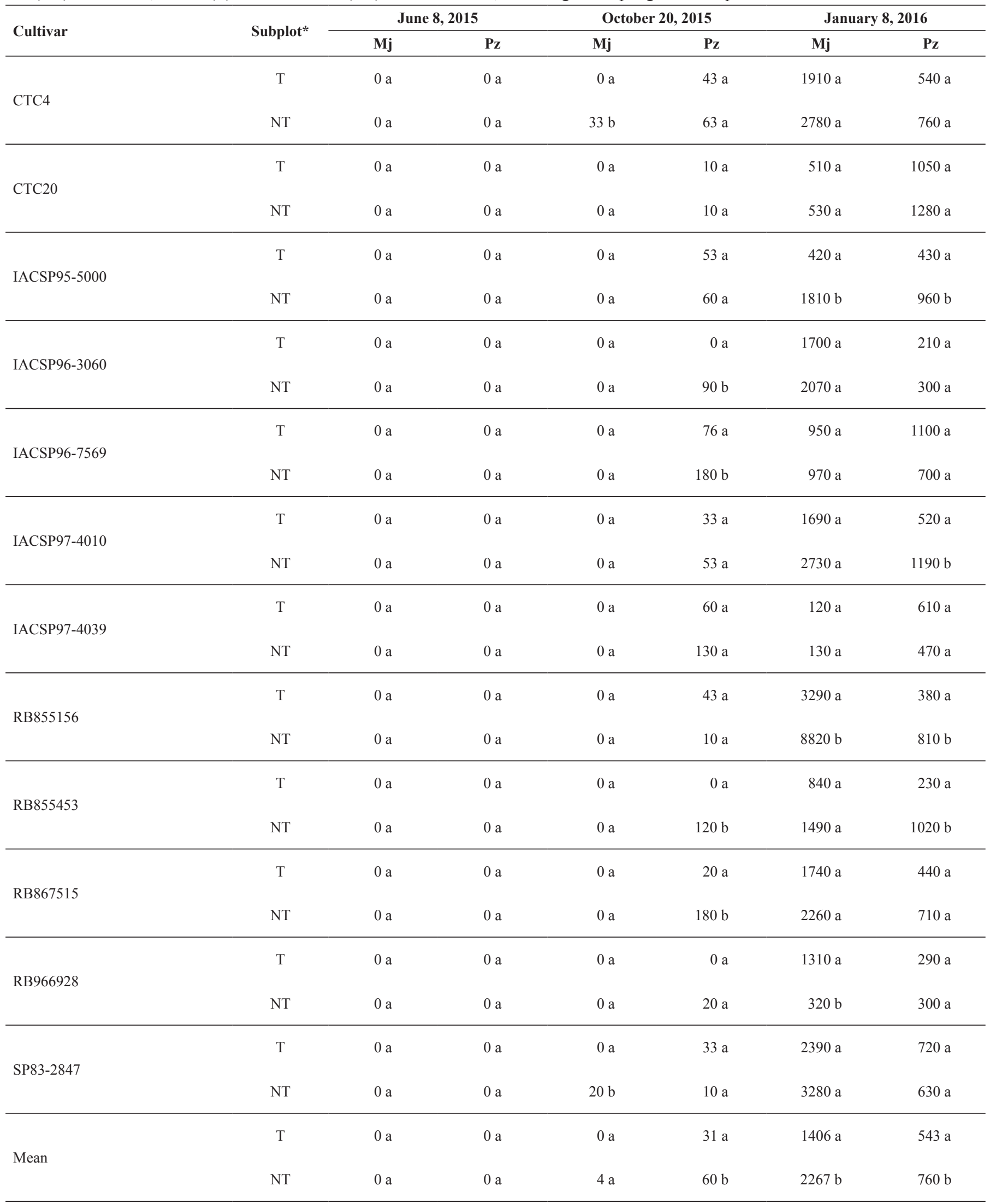

* Treated (T) and non-treated (NT) with nematicide. Means within the same cultivar and in the same column, followed by the same letter, are not significantly different ( $\mathrm{t}$ test, $\mathrm{p} \leq 1)$. 
Table 5. Rainfall $\left(\mathrm{mm} \mathrm{month}^{-1}\right)$ and temperature means recorded during the period when experiments 1 and 2 were conducted.

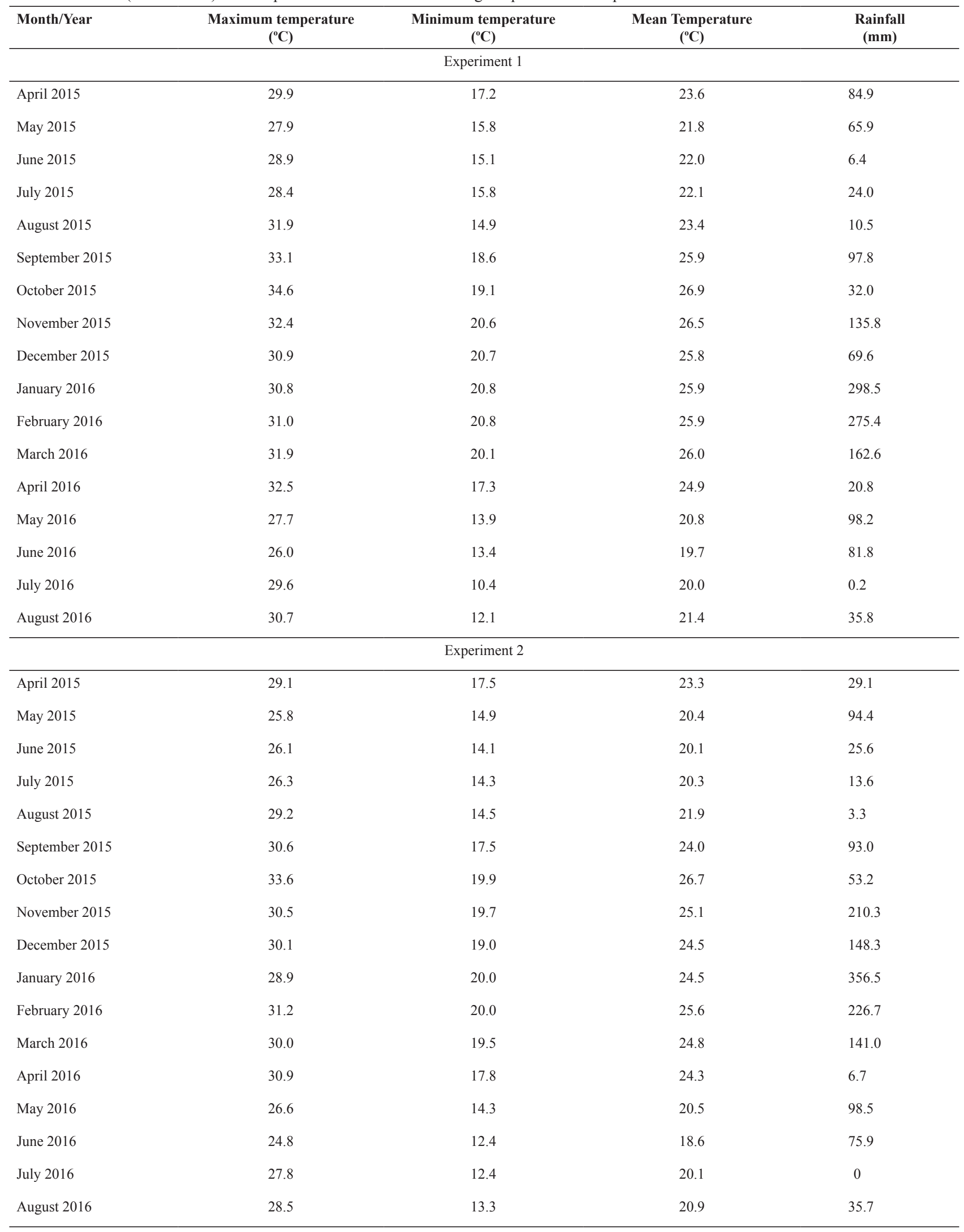


Table 6. Population of second-stage juveniles of Meloidogyne javanica and population of juveniles and adults of Pratylenchus zeae in roots (50 g) of cultivars (mean of treated and non-treated subplots) in experiment 1.

\begin{tabular}{|c|c|c|}
\hline Cultivar & Meloidogyne javanica & Pratylenchus zeae \\
\hline СТС9001 & 265 def & 5454 a \\
\hline СТC9002 & $798 \mathrm{bc}$ & $2347 \mathrm{de}$ \\
\hline СТС9003 & 133 def & $4558 \mathrm{ab}$ \\
\hline IACSP93-3046 & $15 \mathrm{f}$ & $4362 \mathrm{ab}$ \\
\hline IACSP95-5000 & $148 \mathrm{def}$ & $2992 \mathrm{~cd}$ \\
\hline IACSP95-5094 & $453 \mathrm{cdef}$ & $4641 \mathrm{ab}$ \\
\hline IACSP96-3060 & $1790 \mathrm{a}$ & $2809 \mathrm{cde}$ \\
\hline IACSP96-7569 & $70 \mathrm{ef}$ & $3538 \mathrm{bc}$ \\
\hline IACSP97-4039 & 573 bcde & $4393 \mathrm{ab}$ \\
\hline RB965902 & $1650 \mathrm{a}$ & $2004 \mathrm{e}$ \\
\hline RB975201 & 500 bcde & $2677 \mathrm{de}$ \\
\hline RB975242 & $970 \mathrm{bc}$ & $3123 \mathrm{~cd}$ \\
\hline RB975952 & $2510 \mathrm{a}$ & $2579 \mathrm{de}$ \\
\hline
\end{tabular}

Means within the same column, followed by the same letter, are not significantly different (t test, $p \leq 1)$.

Table 7. Population of second-stage juveniles of Meloidogyne javanica and population of juveniles and adults of Pratylenchus zeae in roots (50 g) of cultivars (mean of treated and non-treated subplots) in experiment 2.

\begin{tabular}{|c|c|c|}
\hline Cultivar & Meloidogyne javanica & Pratylenchus zeae \\
\hline CTC4 & 5042 a & $6933 \mathrm{bcd}$ \\
\hline СТC20 & $2008 \mathrm{~cd}$ & $13592 \mathrm{a}$ \\
\hline IACSP95-5000 & $2875 \mathrm{bcd}$ & $6258 \mathrm{bcd}$ \\
\hline IACSP96-3060 & $3817 \mathrm{abc}$ & 4792 de \\
\hline IACSP96-7569 & $1975 \mathrm{~d}$ & $9183 \mathrm{~b}$ \\
\hline IACSP97-4010 & $5867 \mathrm{a}$ & $9867 \mathrm{~b}$ \\
\hline IACSP97-4039 & $2483 \mathrm{~cd}$ & $7467 \mathrm{bcd}$ \\
\hline RB855156 & 7017 a & $8225 \mathrm{bc}$ \\
\hline RB855453 & $4800 \mathrm{ab}$ & 5642 cde \\
\hline RB867515 & 5483 a & $7600 \mathrm{bcd}$ \\
\hline RB866928 & $2733 \mathrm{~cd}$ & 4183 e \\
\hline SP83-2847 & $4500 \mathrm{abc}$ & $7833 \mathrm{bc}$ \\
\hline
\end{tabular}

Means within the same column, followed by the same letter, are not significantly different ( $t$ test, $p \leq 1)$. 
Table 8. Crop stand (stalks. $\left.\mathrm{m}^{-1}\right)$, stalk weight (g), yield (ton.ha ${ }^{-1}$ ) of each cultivar, treated (T) and non-treated (NT) with nematicide at the furrow, and yield increase $(\%)$ due to nematicide, in experiment 1.

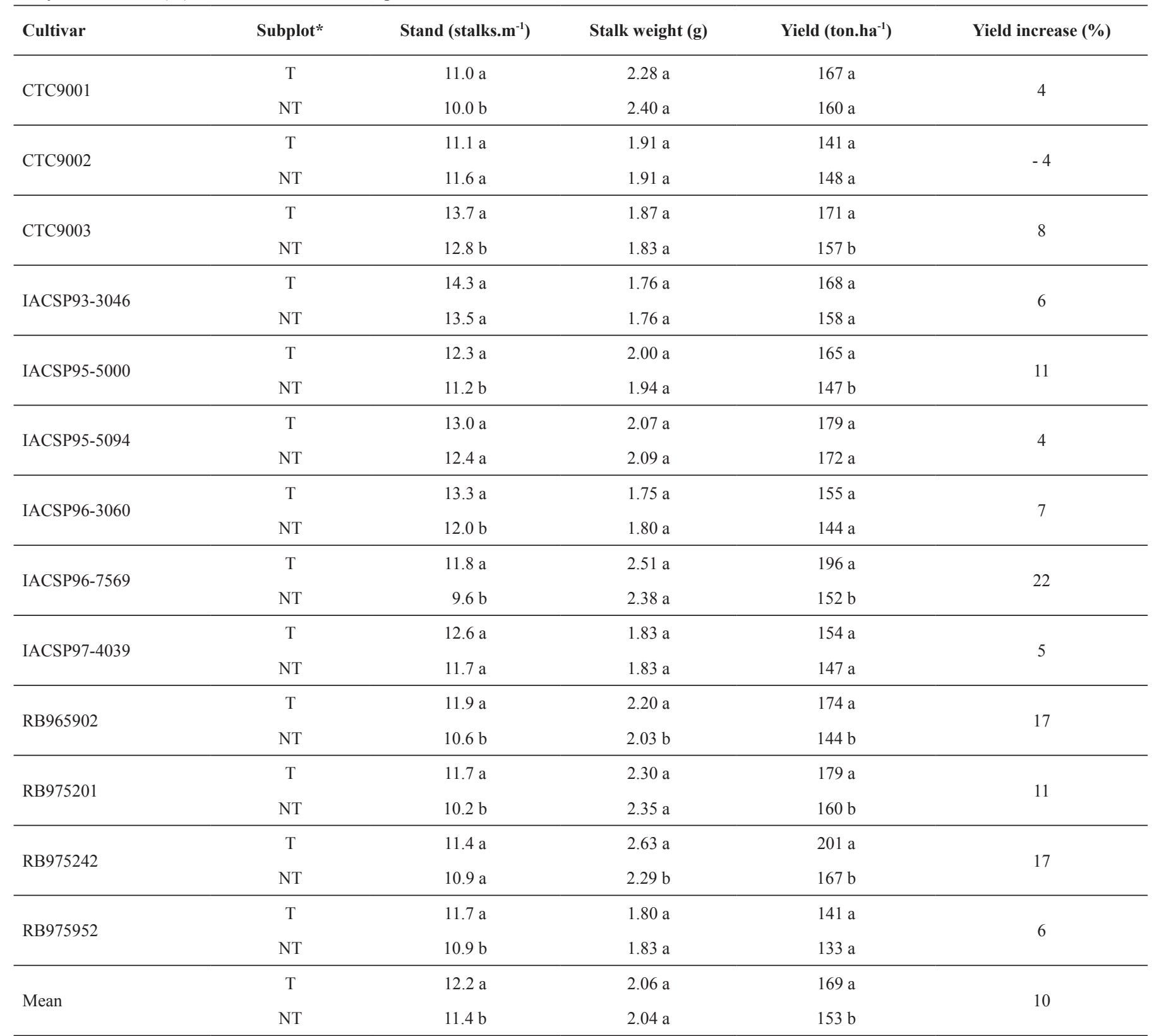

* Treated (T) and non-treated (NT) with nematicide. Means within the same cultivar and in the same column, followed by the same letter, are not significantly different ( $t$ test, $p \leq 1)$.

Although cultivar RB965902 presented one of the largest populations of $M$. javanica, it was the poorest host to $P$. zeae, which had the smallest population in this cultivar. The largest population of P. zeae was observed for CTC 9001 (Table 6).

In experiment 2, the populations of $M$. javanica were largest in roots of RB855156, IACSP97-4010, RB867515 and CTC4, and smallest in IACSP96-7569. Considering $P$. zeae, the population was largest in CTC20 and smallest in RB966928 (Table 7).

Although cultivar RB966928 was the poorest host to P. zeae in the present study, it was considered a good host to this species in studies conducted in pots by Bellé et al. (1), showing a reproduction factor of 8.5. Those authors also considered RB966928 a good host to $M$. javanica, since the reproduction factor was 36.4 .

The cultivar RB966928 was also considered a good host to $M$. javanica by Dias-Arieira et al. (4) in a study using pots; the reproduction factor of $M$. javanica in roots was 2.7. Those authors also considered good hosts to $M$. javanica the cultivars CTC4, RB855156 and RB867515, which presented the largest $M$. javanica populations in experiment 2 (Table 3 ).

Comparing the experimental fields, nematode populations were different but, in general, the cultivars presented similar behavior. IACSP96-3060, for example, was one of the cultivars with the largest 
Table 9. Yield (ton.ha ${ }^{-1}$ ) of each cultivar, treated (T) and non-treated (NT) with nematicide at the furrow, and yield increase (\%) due to nematicide, in experiment 2.

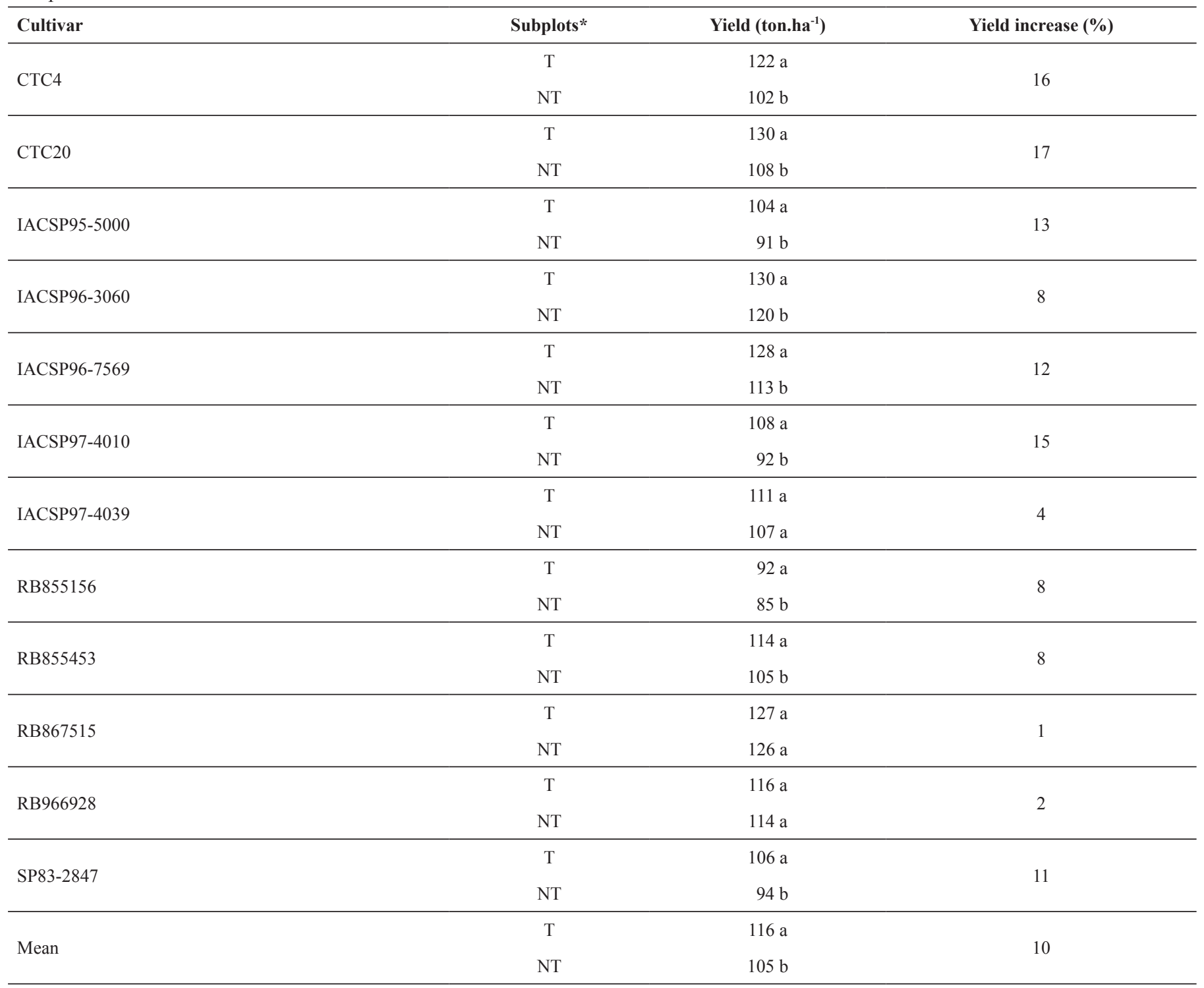

* Treated (T) and non-treated (NT) with nematicide. Means within the same cultivar and in the same column, followed by the same letter, are not significantly different ( $\mathrm{t}$ test, $\mathrm{p} \leq 1)$.

M. javanica populations in both experiments; similarly, IACSP96-7569 was one of the cultivars that presented the smallest populations of this species. The cultivar IACSP96-3060 also presented one of the smallest P. zeae populations in both experiments (Tables 6 and 7).

Using the nematicide improved the crop stand, increasing the number of stalks per meter of furrow for most cultivars in experiment 1, except for CTC9002, IACSP95-5094 and IACSP97-3047. For these cultivars, there was no difference between the treated and the non-treated subplots considering the crop stand (Table 8). On the other hand, stalk weight was less influenced by the use of the nematicide; the stalks of treated subplots were heavier than those of non-treated subplots only for cultivars RB965902 and RB975242 (Table 8). Therefore, these results show that, in the present study, nematodes impacted the yield especially by reducing the crop stand, expressed as number of stalks per meter. On average, subplots treated with the nematicide presented $7 \%$ more stalks $\left(0.8\right.$ tillers. $\left.\mathrm{m}^{-1}\right)$ than non-treated subplots (Tables 8$)$.
For all cultivars, except CTC9002, the yield was higher in treated subplots, compared to non-treated subplots, but this difference was only significant for cultivars CTC9003, RB965902, RB975201, RB975242, IACSP95-5000 and IACSP96-7569. For these cultivars, the difference between treated and non-treated subplots varied from $8 \%$ for CTC9003 to $22 \%$ for IACSP97-3049. On average, the use of the nematicide increased the yield by $10 \%$, suggesting that the damage caused by nematodes to sugarcane, under the conditions of experiment 1 , was a reduction of at least $10 \%$ in the yield (Table 8 ).

The same reduction in the yield due to nematodes was observed in experiment 2, but the increase in the yield due to nematode control was not significant for cultivars RB867515, IACSP97-4039 and RB966928 (Table 9).

Since some cultivars did not show significant differences in yield between treated and non-treated subplots but, in general, presented a large population of at least one nematode species in their roots, they 
could be considered tolerant to nematodes, according to the criteria adopted by Dropkin and Nelson (11). In fact, the following cultivars are more tolerant to nematodes: CTC9001, CTC9002, RB975952, IACSP93-3046, IACSP95-5094, IACSP96-3060 and IACSP97-4039 (experiment 1), and RB8675-15, IACSP97-4039 and RB96-6928 (experiment 2); however, it is important to consider that even these cultivars had greater production in subplots treated with the nematicide, compared to non-treated subplots (Tables 8 and 9). This suggests that, under higher infestations, especially during the initial development of plants, damage due to nematodes could be significant. In both trials, nematode populations remained relatively small during the beginning of the crop development, as observed in the first sampling, at two months after planting. Since plants are more susceptible to the action of nematodes when they are younger, the damages would probably have been greater if the planting had been done during the rainy season, which is more favorable to a more rapid growth of nematode populations.

\section{REFERENCES}

1. Belle, C.; Kulczynsky, S.M.; Kuhn, P.R.; Donini, L.P.; Gomes, C.B. Reaction of sugarcane genotypes to parasitism of Meloidogyne javanica and Pratylenchus zeae. Revista Caatinga, Mossoró, v.30, n.2, p.530-535, 2015.

2. Caveness, F.E.; Badra, T. Control of Helicotylenchus multicinctus and Meloidogyne javanica in stablished plantain and nematode survival as influenced by rainfall. Nematropica, Alabama, v.10, n.1, p.10-14,1980

3. Coolen, W.A.; D'Herde, C.J. A method for the quantitative extraction of nematodes from plant tissue. Ghent: State Nematology and Entomology Research Station. 1972. 64p.

4. Dias-Arieira, C.R.; Santos, D.A.,; Souto, E.R.; Biela, F.; Chiamolera, F.M.; Cunha, T.P.L.; Santana, S.M.; Puerani, H.H. Reação e variedades de canade-açúcar aos nematoides das galhas. Nematologia Brasileira, Piracicaba, v.34, n.4, p.198-203, 2010.

5. Dinardo-Miranda, L.L.; Ferraz, L.C.C.B. Patogenicidade de Pratylenchus brachyurus e Pratylenchus zeae a duas variedades de cana-de-açúcar (Saccharum sp.). Nematologia Brasileira, Piracicaba, v.15, n.1, p.9-16, 1991.

6. Dinardo-Miranda, L.L.; Fracasso, J.V.; Xavier, M.A. Reação de variedades de cana-de-açúcar a Meloidogyne javanica. In: Congresso Nacional da STAB, 9., 2008, Maceió. Anais. Maceió: STAB, 2008. p.133-136.

7. Dinardo-Miranda, L.L.; Fracasso, J.V. Reação de genótipos de cana-de-açúcar a meloidogyne javanica. In: Congresso Nacional da STAB, 10., Ribeirão Preto, 2016. Anais. Ribeirão Preto: STAB, 2016. p.6-99.
8. Dinardo-Miranda, L.L.; Menegatti, C.C.; Garcia, V.; Silva, S.F.; Odorisi, M. Reação de variedades de cana-de-açúcar a Pratylenchus zeae. STAB - Açúcar, Álcool e Subprodutos, Piracicaba, v.17, n.3, p 39-41, 1998.

9. Dinardo-Miranda, L.L.; Morelli, J.L.; Landell, M.G.A.; Silva, M.A. Comportamento de genótipos de cana-de-açúcar em relação a Pratylenchus zeae. Nematologia Brasileira, Piracicaba, v.20, n.2, p. 52-58, 1996

10. Dinardo-Miranda, L.L. Nematoides e pragas da cana-de-açúcar. Campinas: Instituto Agronômico, 2014. 400p.

11. Dropkin, V.H.; Nelson, P.E. The histopathology of root-knot nematode infections in soybeans. Phytopathology, Saint Paull, v. 50, 442-447, 1960.

12. Huang, S.P.; Pereira, A.C. Influence of inoculum density, host, and low-temperature period on delayed hatch of Meloidogyne javanica eggs. Journal of Nematology, Hyattville, v.26, n.1, p. 72-75, 1994.

13. Jenkins, W.R. A rapid centrifugal-flotation technique for separating nematodes from soil. Plant Disease Reporter, Beltsville, v.48, p.692. 1964.

14. Landell, M.G.A.; Vasconcelos, A.C.M. ; Silva, M.A.; Perecin, D.; Barbosa, V.; Penna, M.J. Validação de métodos de amostragem para estimativa de produção de cana-de-açúcar, em áreas de colheita mecanizada. STAB Açúcar, Álcool e subprodutos, Piracicaba, v.18, n.3, p.48-51, 1999.

15. Lordello, L.G.E. Nematóides das plantas cultivadas. São Paulo: Nobel, 1981. 314p.

16. McSorley, R. Population dynamics. In: Barker, K.R.; Pederson, G.A.; Windham, G.L. Plant nematode interactions. Madison: ASA, CSSA and SSSA, 1998. p.109-133.

17. Moura, R.M.; Régis, E.M.O.; Moura, A.M. Espécies e raças de Meloidogyne assinaladas em cana-de-açúcar no Estado do Rio Grande do Norte, Brasil. Nematologia Brasileira, Piracicaba, v.14, n.1, p. 33-38, 1990.

18. Noe, J.P. Development of Meloidogyne arenaria on peanut and soybean under two temperature cycles. Journal of Nematology, Hyattville, v.23, n.3, p.468-476, 1991

19. Novaretti, W.R.T; Terán, F.O. Controle de nematóides parasitos da canade-açúcar. In: Reunião Técnica Agronômica, 1., Piracicaba, 1983. Anais. São Paulo: Copersucar, 1983. p.16-24.

20. Régis, E.M.O.; Moura, R.M. Comportamento de cinco variedades de canade-açúcar em relação ao parasitismo de Meloidogyne incognita raça 1. Nematologia Brasileira, Piracicaba, v.13, n.2, p. 109-118, 1989.

21. SAS Institute.SAS/STAT: User>s guide, version 8.1. Cary 2000. v.1.

22. Sultan, S.A.; Ferris, H. (1991). The effect of soil moisture and soil particle size on the survival and population increase of Xiphinema index. Revue de Nematologie, Paris, v.13, n.2, p. 345-351, 1991.

23. Vasconcelos, A.C.M. Dinâmica do desenvolvimento do sistema radicular da cana-de-açúcar. In Vasconcelos, A.C.M.; Dinardo-Miranda, L.L. Dinâmica do desenvolvimento do sistema radicular da cana-de-açúcar e implicações no controle de nematoides. Americana: Adonis, 2006. p.7-36. 